\title{
Understanding Support for the War in Iraq during the Bush Years: Differences in Civilian and Military Opinion
}

\author{
Roy A. Dawes and Hunter Bacot
}

We examine relationships between military affiliation and support for the war in Iraq and support for President Bush in five southern states chosen because of their support of Republican presidents and concentration of military families. Using public opinion data, we disentangle the effects of race, military affiliation, age, and ideology on support for President Bush and his prosecution of the war. Of note are differences between civilians and military-affiliated respondents in support for the Iraq War. Incongruence is evident about the direction of the war effort between those who fought the war-members of the military - and those who managed most of the war-President Bush and his administration.

"The majority of the nation no longer supports the way this war is being fought; nor does the majority of our military."

Senator James Webb (D-VA) Response to State of the Union Address January 23, 2007

Senator Webb's words are supported by a poll conducted by (and reported in) The Military Times. The report, published December 2006, stated that "[o]nly 35 percent of the military members polled this year said they approve of the way President Bush is handling the war, while 42 percent said they disapproved" (Hodieme 2006, 1). When asked about the likelihood of success in Iraq, only 50 percent felt confident, down from 83 percent in 2004 (Hodieme 2006).

Although there are methodological and substantive issues with Military Times polls, ${ }^{1}$ these findings can still be considered a reasonable barometer of military opinion. These findings are similar to those reported in a Los Angeles Times/Bloomberg poll that finds a majority of military families disapproving of President Bush's handling of the war in Iraq, which mirrors

Direct all correspondence to Hunter Bacot, University of Arkansas at Little Rock, Institute of Government, 2801 S. University Avenue, Little Rock, AR 72204 (ahbacot@ualr.edu). The corresponding author will provide all data and coding information to those wishing to replicate this study. The authors wish to thank Benjamin Kennedy for his assistance in data analysis, as well as anonymous referees for useful suggestions.

ROY A. DAWES is Associate Professor of Political Science at Gettysburg College.

HUNTER BACOT is Director of the Institute of Government at University of Arkansas at Little Rock.

The American Review of Politics, Vol. 34, Spring, 2013: 47-61

(C)2013 The American Review of Politics 
sentiments of the general public (Fiore 2007). Such sentiments among military members should not surprise observers, however, as the socio-economic characterization of enlisted members of the military (enlisted members) do not differ dramatically from the general public; yet, among those members of the military with commissions, as an Institute for Social and Economic Research and Policy (ISERP) study notes, there is an increase in the members that identify themselves as conservatives and Republicans (Institute for Social and Economic Research and Policy, 2006). In an effort to expand the scope of understanding of military opinion on the Iraq war, we use survey research $^{2}$ to explore public and military opinion on the Iraq War, President Bush's conduct of that war, and overall approval of President Bush. As earlier research finds greater support for Bush and his handling of the war amongst those with military affiliations (in comparison to those without), the differences are not tremendous and display a tendency to converge over time (Dawes and Bacot 2008). ${ }^{3}$ Now, we examine the support of the war and the president in an effort to understand variation across factors deemed germane to such support.

There are also larger related issues related to this study, e.g., why is it that the opinion of members of the military matter? During wartime, is it possible that the opinion of military members is some sort of proxy for opinion leaders that the general public responds to in deference to their military service? Trying to address these questions may help further our understanding of the role of public opinion in shaping public policy (in this case, military policy), and also provides additional information for understanding the conditions under which the public may "rally "round the flag" (Mueller 1973; Eichenberg et al. 2006).

\section{Military Opinion on Military Matters: A Review of Literature}

Are there differences in political attitudes and opinions between members of the military and civilians? Sociologists and political scientists have been trying to determine if this is the case, and, if so, why, for about five decades. Huntington (1957) describes soldiers as conservative, realistic, and pessimistic, and considered this related to higher levels of authoritarianism among military professionals, a necessary part of the military mind. Numerous studies question this link, with many failing to find higher degrees of authoritarianism among soldiers in comparison to non-soldiers (Campbell and McCormack 1957; French and Ernest 1955; Janowitz 1960; Janowitz and Little 1965; Roghmann and Sodeur 1972; but see also Goertzel and Hengst 1971). Moreover, differences in attitudes among military members may also be due to differences in adult political socialization, as well as 
being related to different experiences in the military itself (e.g., combat versus non-combat experience). Jennings and Markus (1977) explored these topics extensively, and conclude that there are not important differences in veterans and non-veterans. Schreiber (1979) generally confirms this, but adds that veterans and non-veterans do differ on opinions about military matters. Veterans are more likely to have positive opinions on the military, but opinions on other issues are not significantly different between the two groups. Bachmann et al. (2000) explicitly test whether socialization or selfselection is responsible for whatever differences do exist, and conclude that socialization mattered but is not as important as self-selection.

One does not necessarily need to be a member of the military to view military and foreign affairs through a different lens. Cohen (1966) identifies a "military policy public" as a sub-group of a "foreign policy public." While these two differ, these are further distinguished from a "general public policy public," especially with regard to attentiveness to military and foreign affairs. However, Gelpi and Feaver (2002) examine the presence of veterans among political elites and find that an increase in the number of veterans in high levels of government decreases the likelihood of American initiation of military force. Yet, when military force is chosen, veteran presence in government increases the intensity with which that force is employed. Still, patterns of elite conflict influence opinion concerning war (Berinsky 2007). Disagreement among elites leads to public division, while elite consensus encourages public support. Accordingly, elite rhetoric should be considered as an important influence on public support for war (Berinsky and Druckman 2007). Feaver and Gelpi (2004) also find that members of the military favor realpolitik missions over humanitarian missions.

Understanding differences in military versus non-military opinion, especially in military affairs, must take place in the context of general public opinion on military issues. While a comprehensive summary of this literature is beyond the scope of this paper, there is research that bears consideration. Hartley and Russet (1992) examine the effects of public opinion on military spending and find that changes in public opinion do influence military spending and policy, particularly on "Soviet military spending," or perceived gaps in U.S. vs. U.S.S.R. military spending. Jentleson (1992) finds that differing contours of public opinion on military intervention are explained by the policy objective of the military mission. Americans are much more likely to be supportive of military intervention when the primary policy objective is to restrain an aggressor state rather than to influence internal governmental and political structures of target states.

Another approach to understanding the role of public opinion in the formation of military policy attempts to analyze "rally effects." Parker $(1995,526)$ presents a new conceptualization of rally events as those that 
"invoke feelings of allegiance to national political institutions and policies." Her analysis of rally forces during the Persian Gulf War includes a significant increase in public support for the president, even though this support recedes to pre-conflict levels after 10 months. In our research, we analyze a period of time that may well be after initial rally effects occur. The time period within which this research takes place is during the later stages of the Iraq War, which is part of Mueller's (2005) comparison of the war in Iraq to the Korean and Vietnam Wars. In the case of Iraq, Mueller $(2005,44)$ finds that "support has declined far more quickly than it did for either the Korean War or the Vietnam War."

Our understanding of the relationship between war and presidential approval is furthered by a spate of articles on Iraq and George W. Bush. According to Voeten and Brewer (2006), the linkage between casualties, war events, and presidential approval is less direct than previously thought. Shifts in aggregate support for the war have a greater impact on presidential approval than perceptions of war success, or approval of the president's handling of the war. In addition, aggregate perceptions of success are more responsive to casualties and key events than are aggregate beliefs about the war's merits. At the same time, Gelpi et al. (2007) conclude that prospective judgments of success predict casualty tolerance, and retrospective judgments of the rightness of the war predict vote choice. These judgments may be influenced by the manipulation of casualty ratio data, the use of which can have strong public information value when used sparingly (Boettcher and Cobb 2006). Finally, Gaines et al. (2007) conclude that partisanship determines interpretations, which in turn determine opinions. Perhaps not surprisingly, those members of the public that are better-informed use those interpretations to shore up their partisan opinions. Our model substitutes ideology, measured on a seven point scale, for partisanship because of the limited utility of party data in these southern states.

The extant research seems to conclude that members of the military and non-military citizens do not evaluate the Commanders-in-Chief or his policies similarly and that these evaluations can be attributed to issue processing differences rather than basic demographics. Given these differences of evaluation emerging in the literature, we assess such differences based on presidential evaluations. We simply want to determine whether there are differences between those affiliated with the military and those that are not associated with the military in their evaluation of President Bush and his policies toward the Iraq War. Having established those differences, we examine other factors that likely explain support and opposition for Bush and his handling of the war. While the current research on the Iraq war is extensive and illuminating, it takes place within boundaries that have not included attention to the impact of these differing portions of the population. 
Our work attempts to expand these horizons to examine whether differences in opinion prevail between military members and civilians.

\section{Analyzing Public Opinion on the Iraq War in South-Atlantic States}

In an effort to evaluate whether differences between military and non-military respondents are maintained in traditionally conservative and "military friendly" environments, we survey households in five southern, (usually) "red" states on their opinions about the Iraq War and the president leading this war. These five south-Atlantic states provide a somewhat unique perspective of opinion as these states are pro-military and were pro-Bush. Roughly estimated, there are nearly 60 military installations in these five states, which comprise about 13 percent of all military installations in the continental United States (military.com 2007).

Given the constitution of the region, we assess whether differences exist between citizens in the military and those not in the military about President Bush and the War in Iraq. To do so, we survey ${ }^{5}$ citizens in these five south-Atlantic states about their approval or disapproval of the President's handling of his job and his handling of the war in Iraq. Assessing a relatively homogenous, Republican political region lends to our understanding of military versus non-military perspectives toward the war and Commander-in-Chief.

Bivariate analyses allows us to conclude that, while those affiliated with the military are supportive of the war in Iraq, this support wanes when considered relative to the president's handling of the war. Consequently, while those affiliated with the military are more likely to be supportive of the war, they are not so supportive of their commander-in-chief. Supplementing the initial analysis with additional data from February and November 2007, we examine whether these original differences continue, and whether those differences are magnified or attenuated; we find that not much changes. Focusing on the questions pertaining to presidential support and opinions concerning his handling of the war, we employ Multinomial Logistic Regression analysis (MNL) to understand additional factors at work for determining variation in response to these survey items. ${ }^{6}$ We offer two MNLs for each of the time periods with the categorical response variables serving as the dependent variables. ${ }^{7}$ In addition to the military affiliation independent variable, we include demographic controls (age and race), as well as ideological predisposition (ideology). ${ }^{8}$ Results from these models are presented in Tables 1 through 6.

At first glance, perhaps the most remarkable finding is the stability of the models across the three different time periods (or samples). A moderate 
Table 1. MNL Analysis of Determinants of Support for Bush, February 2006, All vs. Strongly Approve

\begin{tabular}{lrrrr}
\hline Variable & $\begin{array}{c}\text { Strongly Disapprove } \\
\text { Coefficient (SE) }\end{array}$ & $\begin{array}{c}\text { Disapprove } \\
\text { Coefficient (SE) }\end{array}$ & $\begin{array}{c}\text { Approve } \\
\text { Coefficient (SE) }\end{array}$ \\
\hline Age & $.19(.07)^{*}$ & $.07(.07)$ & $-.12(.06)^{*}$ \\
Ideology & $1.27(.09)^{*}$ & $1.01 \quad(.09)^{*}$ & $.35(.08)^{*}$ \\
Race & $17.95(2.55)^{*}$ & $16.47(2.63)^{*}$ & $4.77(2.61)$ \\
Military Affiliation & $-.42(.24)$ & $-.29(.27)$ & $-.24(.22)$ \\
Intercept & $-20.23(2.37)^{*}$ & $-18.09(2.45)^{*}$ & $-4.39(2.36)$ \\
Naglekerke $\mathrm{R}^{2}$ & .39 & & & \\
$\mathrm{~N}$ & 1120 & & & \\
LL $=823.82 ; * \mathrm{p}<.05$ & & & & \\
Note: The estimates were produced by Multinomial Logistic Regression (MNL) & \\
\hline
\end{tabular}

Table 2. MNL Analysis of Determinants of Support for Bush's Handling of the Iraq War, February 2006, All vs. Strongly Approve

\begin{tabular}{lccc}
\hline Variable & $\begin{array}{c}\text { Strongly Disapprove } \\
\text { Coefficient (SE) }\end{array}$ & $\begin{array}{c}\text { Disapprove } \\
\text { Coefficient (SE) }\end{array}$ & $\begin{array}{c}\text { Approve } \\
\text { Coefficient (SE) }\end{array}$ \\
\hline Age & $.17(.07)^{*}$ & $.05(.08)$ & $.004(.07)$ \\
Ideology & $1.19(.09)^{*}$ & $.92(.10)^{*}$ & $.30(.09)^{*}$ \\
Race & $14.26(2.50)^{*}$ & $11.09(2.57)^{*}$ & $-1.66(2.76)$ \\
Military Affiliation & $-.78(.25)^{*}$ & $-.78(.27)^{*}$ & $-.71(.22)^{*}$ \\
Intercept & $-16.09(2.33)^{*}$ & $-12.35(2.40)^{*}$ & $1.44(2.50)$ \\
Naglekerke $\mathrm{R}^{2}$ & .35 & & \\
$\mathrm{~N}$ & 1123 & & \\
LL $=805.87 ; * \mathrm{p}<.05$ & & & \\
Notes: The estimates were produced by Multinomial Logistic Regression (MNL). & \\
\hline
\end{tabular}


Table 3. MNL Analysis of Determinants of Support for Bush, February 2007, All vs. Strongly Approve

\begin{tabular}{lccc}
\hline Variable & $\begin{array}{c}\text { Strongly Disapprove } \\
\text { Coefficient (SE) }\end{array}$ & $\begin{array}{c}\text { Disapprove } \\
\text { Coefficient (SE) }\end{array}$ & $\begin{array}{c}\text { Approve } \\
\text { Coefficient (SE) }\end{array}$ \\
\hline Age & $.05(.10)$ & $-.09(.10)$ & $-.13(.09)$ \\
Ideology & $1.25(.13)^{*}$ & $.96(.13)^{*}$ & $.41(.12)^{*}$ \\
Race & $-2.04(.45)^{*}$ & $-1.62(.47)^{*}$ & $-1.06(.45)^{*}$ \\
Military Affiliation & $-.71(.33)^{*}$ & $-.82(.36)^{*}$ & $-.23(.30)$ \\
Intercept & $-1.55(.67)^{*}$ & $-.73(.68)$ & $.88(.64)$ \\
Naglekerke $\mathrm{R}^{2}$ & .35 & & \\
$\mathrm{~N}$ & 634 & & \\
LL $=638.55 ; * \mathrm{p}<.05$ & & & \\
Notes: The estimates were produced by Multinomial Logistic Regression (MNL). & \\
\hline
\end{tabular}

Table 4. MNL Analysis of Determinants of Support for Bush's Handling of the Iraq War, February 2007, All vs. Strongly Approve

\begin{tabular}{lccc}
\hline Variable & $\begin{array}{c}\text { Strongly Disapprove } \\
\text { Coefficient (SE) }\end{array}$ & $\begin{array}{c}\text { Disapprove } \\
\text { Coefficient (SE) }\end{array}$ & $\begin{array}{c}\text { Approve } \\
\text { Coefficient (SE) }\end{array}$ \\
\hline Age & $-.26(.12)^{*}$ & $-.41(.12)^{*}$ & $-.41(.12)^{*}$ \\
Ideology & $1.07(.14)^{*}$ & $.77(.14)^{*}$ & $.10(.14)$ \\
Race & $-1.57(.48)^{*}$ & $-.62(.51)$ & $-.26(.50)$ \\
Military Affiliation & $-.75(.35)^{*}$ & $-1.71(.42)^{*}$ & $-.36(.33)$ \\
Intercept & $.65(.78)$ & $1.26(.81)$ & $2.89(.78)^{*}$ \\
Naglekerke $\mathrm{R}^{2}$ & .37 & & \\
$\mathrm{~N}$ & 628 & & \\
LL $=578.39 ; * \mathrm{p}<.05$ & & & \\
Notes: The estimates were produced by Multinomial Logistic Regression (MNL). & \\
\hline
\end{tabular}


Table 5. MNL Analysis of Determinants of Support for Bush, November 2007, All vs. Strongly Approve

\begin{tabular}{lccc}
\hline Variable & $\begin{array}{c}\text { Strongly Disapprove } \\
\text { Coefficient (SE) }\end{array}$ & $\begin{array}{c}\text { Disapprove } \\
\text { Coefficient (SE) }\end{array}$ & $\begin{array}{c}\text { Approve } \\
\text { Coefficient (SE) }\end{array}$ \\
\hline Age & $.25(.07)^{*}$ & $.04(.08)$ & $-.03(.07)$ \\
Ideology & $1.06(.09)^{*}$ & $.62(.10)^{*}$ & $.15(.09)$ \\
Race & $2.20(.43)^{*}$ & $1.84(.44)^{*}$ & $.31(.45)$ \\
Military Affiliation & $-.68(.26)^{*}$ & $-.67(.28)^{*}$ & $-.39(.25)$ \\
Intercept & $-5.44(.68)^{*}$ & $-3.25(.68)^{*}$ & $.37(.64)$ \\
Naglekerke $\mathrm{R}^{2}$ & .33 & & \\
$\mathrm{~N}$ & 1222 & & \\
LL $=916.41 ; * \mathrm{p}<.05$ & & & \\
Notes: The estimates were produced by Multinomial Logistic Regression (MNL). & \\
\hline
\end{tabular}

Table 6. MNL Analysis of Determinants of Support for Bush's Handling of the Iraq War, November 2007, All vs. Strongly Approve

\begin{tabular}{lccc}
\hline Variable & $\begin{array}{c}\text { Strongly Disapprove } \\
\text { Coefficient (SE) }\end{array}$ & $\begin{array}{c}\text { Disapprove } \\
\text { Coefficient (SE) }\end{array}$ & $\begin{array}{c}\text { Approve } \\
\text { Coefficient (SE) }\end{array}$ \\
\hline Age & $.13(.08)$ & $-.06(.08)$ & $-.02(.08)$ \\
Ideology & $1.01(.10)^{*}$ & $.65(.10)^{*}$ & $.14(.10)$ \\
Race & $1.27(.37)^{*}$ & $.74(.38)$ & $-1.02(.42)^{*}$ \\
Military Affiliation & $-.91(.26)^{*}$ & $-.81(.28)^{*}$ & $-.29(.25)$ \\
Intercept & $-3.54(.63)^{*}$ & $-1.59(.65)^{*}$ & $1.76(.64)^{*}$ \\
Naglekerke $\mathrm{R}^{2}$ & .31 & & \\
$\mathrm{~N}$ & 1259 & & \\
LL $=888.62 ; *=p<.05$ & & & \\
Notes: The estimates were produced by Multinomial Logistic Regression (MNL). & \\
\hline
\end{tabular}


amount of variation is explained by each of these models - the Nagelkerke (Pseudo) R-square statistic ranges from a low of .31 to a high of .39. ${ }^{9}$ The coefficients in the Strongly Disapprove columns are the effect of a given variable on the probability of strongly disapproving President Bush or his handling of the war versus approving President Bush or his handling of the war. In the next two columns are the effect of a given variable on the probabilities of "disapproving" or "approving," compared to strongly approving.

These coefficients are challenging to interpret directly, so we generated predicted probabilities of choosing the different response categories for military and non-military respondents for the "average" respondent, a white, moderate 45 to 54 year old. Tables 7 through 9 display these results. There was not much startling about these results, beyond confirming most of what we found when examining the original bivariate relationships. Support for Bush and his war policy was waning among those affiliated with the military and those who were not. There were differences between the two categories, but those differences were often seen as converging.

Turning to the classification results of the MNL models (see Table 10), we show that each case falls into a predicted response category, the category with the highest probability predicted by the model. The table summarizes the cases correctly predicted by the model, and compares that percentage to the null model where the modal category is chosen for all cases. Again, the model displays notable improvement over the null model (where the independent variables are presumed to have no effect).

\section{Discussion and Conclusion}

When controls are entered for age, ideology, and race, the indicator of military affiliation fails to maintain statistical significance as far as support for President Bush is concerned. Thus, it appears that differences in the bivariate case are more likely due to differences in the control variables. However, military affiliation is statistically significant when inquiring about President Bush's handling of the war (as are the other control variables, with the exception of age). This should not be interpreted as overall support for his war policies among those affiliated with the military. Indeed, those who either approve or strongly approve never exceeded 50 percent (with the highest support being 48.9\% [Dawes and Bacot 2008]).

Differences between civilians and military-affiliated respondents in support for the Iraq War are unlike differences in support for President Bush. Support for both- the president and the War-among each group erodes steadily over time. The purpose of this paper is to gain insight into some of the nuances of those differences by investigating an area of the country believed to be ardent supporters of President Bush and his policies, as well as 
Table 7. Predicted Probabilities of Support for Bush and His Handling of the Iraq War, 2006

\begin{tabular}{lcccc}
\hline & $\begin{array}{c}\text { Pr } \\
\text { (Strongly } \\
\text { Disapprove) }\end{array}$ & $\begin{array}{c}\text { Pr } \\
\text { (Dilitary }\end{array}$ & $\begin{array}{c}\text { Pr } \\
\text { (Approve) }\end{array}$ & $\begin{array}{c}\text { Pr } \\
\text { (Strongly } \\
\text { Approve) }\end{array}$ \\
\hline Bush Approval & & & & \\
$\quad$ Affiliated & 35 & 20 & 27 & 18 \\
Not & 40 & 20 & 26 & 14 \\
Difference & 5 & 0 & -1 & -4 \\
Handling of War & & & & \\
Affiliated & 36 & 22 & 26 & 16 \\
Not & 40 & 24 & 28 & 8 \\
Difference & 4 & 2 & 2 & -8 \\
\hline
\end{tabular}

Table 8. Predicted Probabilities of Support for Bush and His Handling of the Iraq War, February 2007

\begin{tabular}{lcccc}
\hline & $\begin{array}{c}\text { Pr } \\
\text { (Strongly } \\
\text { Disapprove) }\end{array}$ & $\begin{array}{c}\text { Pr } \\
\text { (Disapprove) }\end{array}$ & $\begin{array}{c}\text { Pr } \\
\text { (Approve) }\end{array}$ & $\begin{array}{c}\text { Pr } \\
\text { Approve) }\end{array}$ \\
\hline Bush Approval & & & & \\
Affiliated & 36 & 20 & 30 & 15 \\
Not & 43 & 26 & 22 & 9 \\
Difference & 7 & 6 & -8 & -6 \\
Handling of War & & & & \\
Affiliated & 48 & 14 & 28 & 10 \\
Not & 44 & 34 & 17 & 4 \\
Difference & -4 & 20 & -11 & -6 \\
\hline
\end{tabular}


Table 9. Predicted Probabilities of Support for Bush and His Handling of the Iraq War, November 2007

\begin{tabular}{lcccc}
\hline & $\begin{array}{c}\text { Pr } \\
\text { (Strongly } \\
\text { Disapprove) }\end{array}$ & $\begin{array}{c}\text { Pr } \\
\text { (Disapprove) }\end{array}$ & $\begin{array}{c}\text { Pr } \\
\text { (Approve) }\end{array}$ & $\begin{array}{c}\text { Pr } \\
\text { (Strongly } \\
\text { Approve) }\end{array}$ \\
\hline Bush Approval & & & & \\
Affiliated & 40 & 19 & 28 & 13 \\
Not & 46 & 22 & 24 & 8 \\
Difference & 6 & 3 & -4 & -5 \\
Handling of War & & & & \\
Affiliated & 39 & 21 & 29 & 11 \\
Not & 50 & 24 & 20 & 6 \\
Difference & 11 & 3 & -9 & -5 \\
\end{tabular}

Table 10. Classification Results of MNL Models

\begin{tabular}{lcc}
\hline Month and Year & $\begin{array}{c}\text { Support for Bush } \\
\text { Percent Correct }\end{array}$ & $\begin{array}{c}\text { Handling of War } \\
\text { Percent Correct }\end{array}$ \\
\hline February 2006 Null & 36.9 & 38.0 \\
MNL & 51.2 & 51.8 \\
February 2007 Null & 40.1 & 43.8 \\
MNL & 52.4 & 54.5 \\
November 2007 Null & 43.7 & 46.3 \\
MNL & 54.5 & 55.0 \\
\hline
\end{tabular}


applying control variables to isolate the affect of military affiliation. Given these findings, that there is disapproval or dissatisfaction with his performance in these "friendly" areas, we are confident that such sentiments among those affiliated with the military prevail outside this region as well.

Some evidence of the softening of President Bush's support among those in the military are found in the Military Times poll. That weak level of support is also apparent in the Los Angeles Times poll. Although these are different samples, these findings are consistent with the polls of the Military Times newspapers, and the one reported in the Los Angeles Times. Perhaps this softening of support is due to a perception about what had already been invested (especially in terms of casualties) in the war from those with military backgrounds or experience. Yet, the support for the war among those affiliated with the military mirrors the general public when President Bush is mentioned in concert with the war. There are differences between civilians and military members, especially on military matters, but those differences are not as vast as once believed. When President Bush and his administration's policies are part of the question, these differences converge, which we believe is tapping into views about the administration's management of the war effort. Evidently, there is incongruence about the direction of the war effort between those fighting the war-members of the military-and those who are managing the war-President Bush and his administration. Thus, Senator Webb's quote rings somewhat true: the military support of the war softens somewhat, but only with regard to their Commander-in-Chief at the time. Regardless, while we expected to see military support for the war effort in Iraq, the convergence of the military and civilian populations on the issue of war was unexpected. These findings also imply that the conventional perception of conservatives (Republicans) holding the upper hand on issues involving patriotism is not apparent in this case. The data analysis also suggests that fatigue with the war is not necessarily limited to the public. War fatigue among the members of the military seems to increase as perceptions of a lack of an enduring mission to the war, i.e., capturing Saddam Hussein versus promoting democracy, increase. The findings that members of the military are more like members of the general public challenges earlier research claiming that members of the military are socialized differently, or have a different set of values than members of the general public. It could indicate that members of the military view the President less as commander-in-chief, and more as the President of the United States (as does the general public).

We intend to pursue this line of research further with additional data on President Barack Obama and his handling of the wars in Afghanistan and Iraq. It will be interesting to uncover whether these phenomena are exclusive to the later years of President Bush's two terms, or if it also extends to President Obama as well. 


\section{NOTES}

${ }^{1}$ The Military Times survey is a mail survey (mailed to their list of active-duty subscribers) whose respondents should not be considered representative of even the military as a whole. Its respondents are "on average older, more experienced, more likely to be officers and more career oriented than the overall military population" (Hodieme 2006, 2).

${ }^{2}$ Our survey research relies on the Elon University Poll conducted in February of 2006 surveyed 1277 randomly selected respondents in five southern states, 265 of whom had some direct connection to the military (though referred to as simply "military," this group includes those affiliated with the military in the following manner: active duty members, members of the reserves, retired military, or military veterans). This poll was updated in February 2007 and again in November 2007. The February 2007 survey included 719 respondents, 156 of whom were connected with the military, and the November 2007 survey's comparable numbers were 1374 and 262, respectively.

${ }^{3}$ This is consistent with Karol and Miguel (2007) who found that casualties from a state depressed Bush's 2004 vote share there. For a contrary view, see Norpoth and Sidman (2007). Kriner and Shen (2009) also found that casualties depressed participation in communities in the wake of the Korean and Vietnam conflicts.

${ }^{4}$ Gelpi (2006) contends that Mueller oversimplifies the phenomenon, and argues that Americans are more "defeat-phobic" than "casualty-phobic."

${ }^{5}$ The surveys were conducted by Elon University Poll using stratified random samples of households with telephones in the population of these five states (Florida, Georgia, North Carolina, South Carolina, and Virginia). The first survey was conducted February 20-23 and February 26-March 2, 2006. Interviews were completed with 1277 adults from households in these states. For a sample size of 1277 , there is a $95 \%$ probability that our survey results are within $\pm 2.8 \%$ (the margin of error) of the actual population distribution for any given question, http://www.elon.edu/e-web/elonpoll/200603.xhtml. The second survey was conducted February 18-22, 2007. The sample size was 719 and the margin of error was $\pm 3.7 \%$, http://www.elon.edu/e-web/elonpoll $/ 022307$ data.doc. The third survey was conducted November 4-8 and November 12-14, 2007. The sample size was 1,374 and the margin of error was $\pm 2.7 \%$, http://www.elon.edu/docs/e-web/elonpoll/ 111607.pdf.

${ }^{6} \mathrm{We}$ use MNL instead of ordered logit because, while the dependent variables are ordinal, we expect that some of the relationships with the independent variable may be non-linear. For example, a person who self-identifies as moderate may have a higher probability of agreeing or disagreeing on the support of Bush questions, but a lower probability of expressing either strong support or opposition.

${ }^{7}$ The dependent variables are based on two survey questions: "Do you [approve or disapprove] of the way George W. Bush is handling his job as president?" and "Do you [approve or disapprove] of the way President Bush is handling the war in Iraq?" (information in brackets is rotated). Response options are scaled from 1, strongly oppose, to 4, strongly support. The question is offered as a probe, meaning that respondents first indicate whether they support/oppose, at which point a follow-up question is asked, e.g., "would you say you strongly support/oppose?"

${ }^{8}$ The original race variable is based on a question asking for one's race and includes these categories: Asian, Black, Hispanic, Multi-racial, Native American, White, and Other. To facilitate analysis, we collapse it into White and Non-white. The age variable is one's age, collapsed into categories. The ideology variable is a seven point scale that 
ranges from "extremely conservative" to "extremely liberal," with a middle category identified as "moderate."

${ }^{9}$ Nagelkerke's (or Cragg and Uhler's) R-squared is used because estimates from multinomial logistic regression are produced through an iterative process, unlike Ordinary Least Squares, which are calculated to minimize variance. Pseudo R-squareds are similar to R-squared in that values range from 0 to 1 (although some never extend to 0 or 1 ), with higher values indicating better model fit. Further, it adjusts Cox \& Snell's R-squared so that the range of values includes 1 .

\section{REFERENCES}

Bachman, Jerald G., Peter Freedman-Doan, David R. Segal, and Patrick M. O’Malley. 2000. Distinctive Military Attitudes among U.S. Enlistees, 1976-1997: Self-Selection versus Socialization. Armed Forces and Society 26(Summer):561-585.

Berinsky, Adam J. 2007. Assuming the Costs of War: Events, Elites, and American Public Support for Military Conflict. Journal of Politics 69:975-997.

Berinsky, Adam J., and James N. Druckman. 2007. Public Opinion Research and Support for the Iraq War. Public Opinion Quarterly 71(Spring):126-141.

Boettcher, William A., and Michael D. Cobb. 2006. Echoes of Vietnam? Casualty Framing and Public Perceptions of Success and Failure in Iraq. Journal of Conflict Resolution 50(December):831-854.

Campbell, Donald T., and Thelma H. McCormack. 1957. Military Experience and Attitudes toward Authority. American Journal of Sociology 62(March):482-490.

Cohen, Bernard C. 1966. The Military Policy Public. Public Opinion Quarterly 30(Summer):200-211.

Dawes, Roy A., and A. Hunter Bacot. 2008. A Dynamic Assessment of Public versus Military Support for the War in Iraq: Evidence from Five Southern States. Paper prepared for presentation at the annual meeting of the Western Political Science Association. San Diego. March.

Eichenberg, Richard C., Richard J. Stoll, and Matthew Lebo. 2006. War President: The Approval Ratings of George W. Bush. Journal of Conflict Resolution 50(December):783-808.

Feaver, Peter D., and Christopher Gelpi. 2004. Choosing Your Battles: American CivilMilitary Relations and the Use of Force. Princeton, NJ: Princeton University Press.

Fiore, Faye, 2007. Bush Loses Ground with Military Families. Los Angeles Times, http://www.latimes.com/news/custom/timespoll/la-na-militpoll7dec07,0,4843202. story?coll=la-home-center, December 11.

French, Elizabeth G., and Raymond R. Ernest. 1955. The Relationship between Authoritarianism and Acceptance of Military Ideology. Journal of Personality 24(December):181-191.

Gaines, Brian J., James H. Kuklinski, Paul J. Quirk, Buddy Peyton, and Jay Verkuilen. 2007. Same Facts, Different Interpretations: Partisan Motivation and Opinion on Iraq. Journal of Politics 69(November):957-974.

Gelpi, Christopher, and Peter D. Feaver. 2002. Speak Softly and Carry a Big Stick? Veterans in the Political Elite and the American Use of Force. American Political Science Review 96(December):779-793.

Gelpi, Christopher. 2006. The Cost of War: How Many Casualties Will Americans Tolerate? Foreign Affairs 85(1):139-144. 
Gelpi, Christopher, Jason Reifler, and Peter D. Feaver. 2007. Iraq the Vote: Retrospective and Prospective Foreign Policy Judgements on Candidate Choice and Casualty Tolerance. Political Behavior 29:151-174.

Goertzel, T., and A. Hengst. 1971. The Military Socialization of University Students. Social Problems 19:258-267.

Hartley, Thomas, and Bruce Russett. 1992. Public Opinion and the Common Defense: Who Governs Military Spending in the United States? American Political Science Review 86(December):905-915.

Hodieme, Robert. 2006. Down on the War, Military Times, http://www.militarycity.com/ polls/2006 main.php, January 26, 2007.

Huntington, Samuel P. 1957. The Soldier and the State: The Theory of Politics and CivilMilitary Relations. Cambridge, MA: Harvard University Press.

Institute for Social and Economic Research and Policy (ISERP). 2006. Citizenship and Service: Political and Social Attitudes of Active-Duty Army and Cadets at the U.S. Military Academy. West Point/Columbia University (Spring) accessed at http://www.iserp.columbia.edu/news/articles/citizenship.html.

Janowitz, Morris. 1960. The Professional Soldier: A Social and Political Portrait. New York: Free Press.

Janowitz, Morris, and Roger W. Little. 1965. Sociology and the Military Establishment. New York: Russell Sage.

Jennings, M. Kent, and Gregory B. Markus. 1977. The Effect of Military Service on Political Attitudes: A Panel Study. American Political Science Review 71(March): 131-147.

Jentleson, Bruce W. 1992. The Pretty Prudent Public: Post Post-Vietnam American Opinion on the use of American Military Force. International Studies Quarterly 36(March):49-73.

Karol, David, and Edward Miguel. 2007. The Electoral Cost of War: Iraq Casualties and the 2004 Presidential Election. Journal of Politics 69(August):639-648.

Kriner, Douglas, and Francis Shen. 2009. Limited War and American Political Engagement. Journal of Politics 71: 1514-29.

Mueller, John. 1973. War, Presidents, and Public Opinion. New York: Wiley.

Mueller, John. 2005. The Iraq Syndrome. Foreign Affairs 84(6):44-54.

Norpoth, Helmut, and Andrew H. Sidman. 2007. Mission Accomplished: The Wartime Election of 2004. Political Behavior 29:175-195.

Parker, Suzanne. 1995. Toward an Understanding of 'Rally' Effects: Public Opinion in the Persian Gulf War. Public Opinion Quarterly 59(Winter):526-546.

Roghmann, Klaus, and Wolfgang Sodeur. 1972. The Impact of Military Service on Authoritarian Attitudes: Evidence from West Germany. American Journal of Sociology 78(September):418-433.

Schreiber, E.M. 1979. Enduring Effects of Military Service? Opinion Differences between U.S. Veterans and Nonveterans. Social Forces 57(March):824-839.

Voeten, Erik, and Paul R. Brewer. 2006. Public Opinion, The War in Iraq, and Presidential Accountability. Journal of Conflict Resolution 50(October):809-830. 